\title{
Globalización, Democracia y Pandemia
}

\section{Globalization, Democracy and Pandemic}

\author{
Ernesto Ottone * \\ FONDATION MAISON DES SCIENCES DE L'HOMME
}

\section{RESUMEN:}

Si bien pueden existir elementos de la globalización que serán fuertemente golpeados por la pandemia, la globalización como contracción del tiempo y el espacio y como tecnología es algo que continuará. ¿Tiene que ser una globalización sin gobernanza global, con un sistema multilateral menor, con paraísos fiscales y con desigualdad creciente? Creemos firmemente que no, que puede existir otra globalización, para ello tiene que haber cambios muy grandes en la política y voluntades muy fuertes de transformación económica. Sostenemos que la globalización no verá su fin por causa de la pandemia, pero se van a producir tendencias al cambio.

Palabras clave: Globalización, economía, política, estructura social, pandemia

\begin{abstract}
:
While there may be elements of globalization that will be hit hard by the pandemic, globalization as a contraction of time and space and as technology is something that will continue. Must it be a globalization without global governance, with a smaller multilateral system, with tax havens and growing inequality? We firmly believe that no, that there can be another globalization, for this there must be very big changes in politics and very strong will for economic transformation. We maintain that globalization will not end because of the pandemic, but there will be trends towards change.
\end{abstract}

Keywords: Globalization, economy, politics, social structure, pandemic

*ernestoottone@gmail.com 


\section{INTRODUCCIÓN}

ara comenzar a discutir es necesario aclarar los conceptos que utilizaremos. Entenderé por globalización la revolución digital que se generó en el 1980 que significó un paso desde la era industrial hacia la de la información. La característica principal de este cambio no se produce en la economía, sino una contracción del tiempo y el espacio.

Ellas son principalmente el resultado de una revolución tecnológica particularmente importante en las comunicaciones. $\mathrm{Su}$ elemento central es naturalmente Internet, puesto que cambia las relaciones tradicionales de emisor-receptor a relaciones donde el emisor es también receptor y viceversa.

Esto genera un cambio significativo en la sociedad. Manuel Castells lo describe como un proceso histórico cultural que crea una sociedad en red y que cambia la forma en cómo los hombres viven, en definitiva, transforma su práctica social.

Esto significa que los mecanismos propios de la sociedad industrial entran en crisis planteando cambios fuertes. Por ejemplo, la educación, la cual ha pasado de ser secuencial hacia un proceso de educación permanente; ocurre lo mismo con el mundo del trabajo, siendo ahora mucho más volátil y donde la esperanza de vida ha aumentado provocando que se discutan cambios en los sistemas de seguridad social.

La familia también ha cambiado, naciendo distintos modelos de organización familiar, alejándose del modelo de familia tradicional. Existe un cambio territorial también, el Estado-nación sigue teniendo importancia, sin embargo, nacen elementos supranacionales, a la par que locales. Aparecen problemas que no encuentran solución en lo nacional como la criminalidad global o los cambios en las formas de relacionarse entre los humanos y la naturaleza.

La globalización está ligada a todos estos cambios, pero también a la economía y a la política. El inicio de la globalización coincide con un conjunto de fenómenos políticos, pero no necesariamente es su causalidad absoluta (fenómenos como la caída de la Unión Soviética y la universalización del capitalismo). En la economía 
coincide con cambios muy importantes, como el debilitamiento del Estado de bienestar y la revolución conservadora de los años 1980 que produce el neoconservadurismo y el neoliberalismo desde un punto de vista político y económico respectivamente, modelos que tuvieron un proceso expansivo al menos hasta el 2008.

Globalización Y ECONOMÍA, ¿QUÉ TENÍAMOS ANTES DE LA PANDEMIA?

Algunos autores han señalado, que posterior los años de creciente globalización, estamos en los ańos de la "fase triste de la globalización" nacidos del quiebre producido luego de la crisis del 2008.

La pregunta es entonces, si esta es la única forma en la que puede existir la globalización Yo creo que no, la globalización llegó para quedarse, si bien pueden existir elementos de la globalización que serán fuertemente golpeados por la pandemia, la globalización como contracción del tiempo y el espacio y como tecnología es algo que continuará. ¿Tiene que ser una globalización sin gobernanza global, con un sistema multilateral menor, con paraísos fiscales y con desigualdad creciente? Yo creo firmemente que no, que puede existir otra globalización, para ello tiene que haber cambios muy grandes en la política y voluntades muy fuertes de transformación económica.

Yo no creo que la globalización vaya a terminar por causa de la pandemia, pero creo que sí se van a producir tendencias al cambio.

No hay que confundir globalización con economía global o globalización con desarticulación económica ni con ausencia de todo tipo de norma regulatoria económica (ausencia de impuestos progresivos, descomposición del Estado de bienestar). Puede haber un nuevo rol del Estado en todo esto, en lo cual es fundamental la centralidad no sólo de los sujetos económicos, sino también del sujeto político.

Justamente hoy, con la pandemia, es necesario volver al sujeto político, alejándose de la individuación extrema; la solución es colectiva, o no hay solución. La negación de la sociedad, como la planteó Margaret Thatcher pierde sentido frente a una realidad como la que estamos viviendo. 
¿Cuál es la globalización con la que se encuentra la pandemia? La economía global tiene tres características principales: (1) un aumento de la desigualdad dentro de los países fruto de la desregulación económica, (2) la disminución de la pobreza global (destaca el caso de India y China que han progresado rápidamente, pero aun existiendo mucha precariedad) y (3) aumento de la convergencia, los países desarrollados continúan su tendencia de lento crecimiento frente al rápido crecimiento de las economías emergentes.

En síntesis, el mundo antes de la pandemia ya venía con serios problemas y conflictos geopolíticos. Además, en los lugares donde la economía crecía mucho estaban comenzando problemas geopolíticos, como lo ocurrido en Asia, sumado a tendencias políticas autoritarias.

No es entonces, necesario definirse como anti o pro-globalización, sino que quizá alter-globalización, es decir, abogar por una globalización diferente, una de otro carácter. Como decía Fernando Savater: ser partidario de la electricidad, no es ser partidario de la silla eléctrica.

\section{Democracia en la époCa De La GLOBALIZACión}

En cuanto al elemento político, lo primero es hablar sobre la democracia. La democracia tiene dos aspectos: una democracia ideal libre de corrupción y de malas intenciones, cuestión que no existe ni existirá; y también hay una democracia real que sí existe y que tiene distintos niveles. La democracia real e imperfecta tiene a su vez dos componentes: la democracia de los procedimientos, de las reglas democráticas y el Estado de derecho,y la democracia exigente, donde además del cumplimiento de las reglas, se requiere un contenido social y económico de ciertos niveles de igualdad mínimos que permitan que el hecho de ejercer ciudadanía tenga sentido.

Estos elementos de la democracia entran a ser cuestionados de la mano de la revolución tecnológica. Hoy existe lo que se llama democracia continua, es decir, donde el ciudadano puede intervenir en cualquier momento más allá de las instituciones democráticas para señalar su descontento o su opinión, en donde el receptor es a la vez un emisor. 
Por lo tanto, esta democracia cambia porque su base tecnológica cambió fuertemente. Se genera entonces, una crisis de las instituciones clásicas de la democracia y de los partidos políticos, quienes ya no son los únicos actores de la democracia. Esto se pone de manifiesto en la apreciación que tiene la ciudadanía de estas instituciones, la cual ha venido a la baja.

Los partidos políticos han comenzado a volverse una cuestión endógena, percibidos por lagente como ajena a sus realidades. Cambia también el electorado, al modificarse la estructura de estratificación social, clase y movilidad social. Los partidos antiguamente tenían cierta representación de clases o de ideas, cuestión que ha cambiado enormemente. Hoy se da, paradójicamente, que partidos de extrema derecha tienen una base obrera y partidos de izquierda tienen base en sectores medios con alto nivel de estudios.

En situaciones como éstas, con crisis en el proceso de globalización y con crisis en el proceso democrático, nos sorprende la pandemia, la cual aparece como un insulto al ego de la modernidad.

Existía una idea de que había un cierto control del ser humano sobre estos fenómenos, los cuales han acompañado a la humanidad en su historia. Si bien ha habido otras pandemias, éstas han estado asociadas a grupos específicos o en geografías específicas, y no necesariamente eran transmitidas solamente por acercarse a una persona. Esta pandemia, por el contrario, fue rápidamente de carácter hiper global y paralizó rápidamente la economía. Se produce entonces, una pandemia que pone en cuestión a los sistemas de salud, pero no solamente a los de países en vías de desarrollo, sino que a todos; pone en cuestión a los sistemas políticos de algunos países.

Es interesante, sean los populismos negacionistas de Trump y Bolsonaro, y populistas como Modi en India quienes niegan la pandemia y terminan con desastres sanitarios. No aparece entonces una fórmula única para detener la pandemia,claro el surgimiento de la vacuna traslada el desafío a la capacidad de la combinación entre ciencia y politicas públicas con mayores esperanzas. 


\section{Conclusión}

¿Cómo será el mundo después de la pandemia? ¿Más democrático o más autoritario? No está clara la respuesta. No hay resultados claros aún. No sabemos quién va a resolver mejor la pandemia, es una cuestión abierta todavía.

Lo que si sabemos es que almenos durante un período será más pobre y probablemente más desigual.

Efectivamente podemos pensar que ciertas cosas cambiarán, como los sistemas de salud. Pero nadie puede dar aún una respuesta contundente de que es lo que depara. La postpandemia.

Fecha recepción: 9 de julio de 2020

Fecha aceptación: 30 de julio de 2020

Versión final: 10 de octubre de 2020 